\title{
Pembangunan Wilayah Pertanian Berbasis Pengembangan Komoditi Tanaman Pangan Dan Perkebunan Kawasan Andalan Kabupaten Bone Provinsi Sulawesi Selatan
}

Development of Agricultural Areas Based on Commodity Development of Food Crops and Plantations in the Mainstay Area of Bone Regency, South Sulawesi Province

\author{
Indrajaya $^{1^{*}}$, Rusida $^{2}$ \\ "Email: indrajaya1067@gmail.com \\ ${ }^{1}$ Fakultas Teknik, Universitas Andi Djemma Palopo \\ ${ }^{2}$ Fakultas Pertanian, Universitas Andi Djemma Palopo
}

Diterima: 15 September 2021 / Disetujui: 24 Desember 2021

\begin{abstract}
ABSTRAK
Tujuan dari penelitian ini adalah untuk mengetahui jenis komoditi unggulan pertanian tanaman pangan dan perkebunan yang menjadi basis produksi pada kawasan andalan Kabupaten Bone Provinsi Sulawesi Selatan. Metode penelitian yang digunakan adalah observasi, data yang dianalisis adalah data sekunder. Data dikumpulkan dari beberapa sumber seperti; Badan Pusat Statistik Kabupaten Bone, Badan Perencanaan Pembangunan Daerah Kabupaten Bone, Dinas Pertanian Tanaman Pangan dan Hortikultura Kabupaten Bone. Metode analisis regional yang digunakan adalah Metode Analisis LQ. Hasil analisis menunjukkan bahwa di Kabupaten Bone terdapat : (i) Dua Puluh wilayah yang sangat unggul untuk pertanian tanaman pangan komoditi padi, Enam wilayah untuk komoditi jagung dan Sembilan wilayah untuk komoditi kacang kedelai, (ii) Dua Puluh Tiga wilayah sangat unggul untuk tanaman perkebunan komoditi kelapa, Delapan wilayah sangat unggul untuk komoditi kopi, Dua Puluh Tiga wilayah sangat unggul untuk komoditi kakao, Tiga wilayah sangat unggul untuk komoditi tembakau dan Tiga wilayah sangat unggul untuk komoditi tembakau.
\end{abstract}

Kata Kunci: Komoditi Pertanian, Tanaman Pangan, Perkebunan, Kawasan Andalan

\section{ABSTRACT}

The purpose of this study was to determine the types of leading agricultural commodities, food crops and plantations which became the production base in the mainstay area of Bone Regency, South Sulawesi Province. The research method used is observation, the data analyzed is secondary data. Data is collected from several sources such as; Central Bureau of Statistics of Bone Regency, Regional Development Planning Agency of Bone Regency, Department of Agriculture of Food Crops and Horticulture of Bone Regency. The regional analysis method used is the LQ. Analysis Method. The results of the analysis show that in Bone Regency there are: (i) Twenty regions that are very superior for rice commodity agriculture, Six regions for corn commodity and nine regions for soybean commodity, (ii) Twenty-three regions are very superior for plantation crops. coconut commodity, Eight regions are very good for coffee commodity, Twenty-three regions are very good for cocoa commodity, Three regions are very good for tobacco commodity and Three regions are very good for tobacco commodity.

Keywords: Food Crop, Agricultural Commodities, Plantation, Mainstay Region

(c) (1) This work is licensed under Creative Commons Attribution License 4.0 CC-BY International license

\section{A. PENDAHULUAN}

Kawasan andalan merupakan

kawasan yang ditetapkan sebagai penggerak perekonomian wilayah (prime

mover), yang memiliki kriteria sebagai

kawasan yang cepat tumbuh dibanding 
lokasi lainnya dalam suatu provinsi, memiliki sektor unggulan dan memiliki keterkaitan ekonomi dengan daerah sekitar (hinterland). Pertumbuhan kawasan andalan diharapkan dapat memberikan kontribusi yang positif bagi pertumbuhan daerah sekitar, melalui pemberdayaan sektor/subsektor unggulan sebagai penggerak perekonomian daerah dan keterkaitan ekonomi antardaerah. Arah kebijakan penetapan kawasan andalan ditekankan pada pertumbuhan ekonomi. Karena pertumbuhan ekonomi merupakan salah satu variabel ekonomi yang merupakan indikator kunci dalam pembangunan.

Sektor pertanian dalam pembangunan ekonomi daerah menjadi salah satu sektor yang penting sebagai upaya mensejahterakan masyarakat. Sektor pertanian berperan pada : (1) penyedia pangan untuk pemenuhan kebutuhan yang semakin meningkat, seiring dengan pertumbuhan penduduk; (2) meningkatkan permintaan produk industri, sehingga perlunya perluasan sektor sekunder dan sektor tersier; (3) meningkatkan devisa untuk impor barangbarang modal bagi pembangunan melalui ekspor hasil pertanian secara terus menerus; (4) meningkatkan pendapatan desa untuk dimobilisasi pemerintah; serta
(5) memperbaiki kesejahteraan rakyat pedesaan.

Kawasan Andalan, dalam Rencana Tata Ruang Wilayah Nasional adalah suatu kawasan yang dikembangkan untuk mengurangi kesenjangan antarwilayah melalui pengembangan kegiatan ekonomi yang diandalkan sebagai motor penggerak pembangunan. Kawasan Andalan diharapkan mampu menjadi pusat dan pendorong pertumbuhan ekonomi bagi kawasan di sekitarnya. Kawasan andalan juga diharap mampu bersaing di dalam dan luar negeri. Kemampuan bersaing ini lahir melalui pengembangan produk unggulan yang kompetitif di pasar domestik maupun global, yang didukung sumberdaya manusia (SDM) unggul, riset dan teknologi, informasi, serta keunggulan pemasaran (Agribisnis).

Kawasan andalan bisa berupa : (i) kawasan yang sudah berkembang, terdapat aglomerasi kota dan aglomerasi kegiatan sektor produksi yang didukung oleh sumberdaya manusia, sumberdaya alam, kedekatan lokasi terhadap pusatpusat pertumbuhan regional, dan telah memiliki infrastruktur pendukung; (ii) kawasan andalan yang prospektif untuk dikembangkan, terdapat sumberdaya alam, mempunyai akses terhadap pusat pertumbuhan, dekat dengan pusat-pusat 
permukiman, serta memungkinkan untuk pengadaan prasarana pendukung. Sebagai pusat pertumbuhan ekonomi, kawasan andalan perlu dikelola secara terpadu, komprehensif, dan berkesinambungan agar lebih terarah dan teratur. Terdapat beberapa aspek pengembangan yang menjadi tolok ukur kelayakan analisis kawasan andalan, yaitu fisik dan lingkungan, ekonomi, sosial budaya, dan kelembagaan.

Sementara itu dalam pelaksanaan di daerah, konsep pengembangan kawasan andalan tidak secara efektif dikembangkan, sehingga tidak pernah dapat diukur keberhasilannya. Maka dibutuhkan model-model pengembangan ekonomi daerah dengan pendekatan kawasan andalan, yang memiliki konsep pengembangan yang terfokus dan terpadu, terutama berorientasi pada karakteristik potensi kawasan dan kemampuan pengembangan kawasan. Salah satu kebijakan yang diambil pemerintah untuk mempersempit disparitas antardaerah adalah diterapkannya kebijakan pembangunan daerah melalui konsep kawasan andalan, berdasarkan potensi yang dimiliki daerah. Dengan kebijakan tersebut diharapkan terjadi keseimbangan tingkat pertumbuhan ekonomi dan pendapatan perkapita antar wilayah.
Dalam dimensi Rencana Tata Ruang Wilayah Provinsi Sulawesi Selatan Kabupaten Bone bersama dengan Kabupaten Bulukumba, Kota Parepare dan Kota Palopo ditetapkan sebagai kawasan andalan Provinsi Sulawesi Selatan

Kawasan Andalan Kabupaten Bone memiliki potensi pertanian tanaman pangan dan perkebunan yang berkembang baik, ditandai dengan peningkatan produksi dari tahun-ketahun mengalami peningkatan. Produksi pertanian tanaman pangan yang diusahakan masyarakat di Kabupaten Bone, meliputi; padi, jagung dan kacang kedelai yang tersebar di 27 kecamatan, jumlah produksi pertanian tanaman pangan untuk tiga jesnis komoditi yang diusahakan masyarakat sebesar 1.808 .587 Ton, terdiri dari padi sawah sebesar 1.393.147 Ton, jagung sebesar 402.396 Ton dan kacang kedelai sebesar 13.044 Ton. Sedangkan tanaman perkebunan yang diusahakan masyarakat meliputi; kelapa, kopi, kakao, tebu, dan tembakau dengan total produksi sebesar 93.764 Ton, terdiri dari kelapa sebesar 12.346 Ton, kopi sebesar 319 Ton, kakao sebesar 10.700 Ton, tebu sebesar 69.634 Ton dan tembakau sebesar 765 Ton.

Tujuan penelitian untuk mengetahui jenis komoditi unggulan pertanian 
tanaman pangan dan perkebunan yang menjadi basis produksi pada kawasan andalan Kabupaten Bone Provinsi Sulawesi Selatan.

\section{B. METODE PENELITIAN}

Metode penelitian dilakukan dengan teknik observasi (kunjungan). Observasi dilakukan dengan cara mengunjungi: lembaga-lembaga pemerintah yang mendokumentasikan kegiatan pembangunan bidang pertanian tanaman pangan dan perkebunan. Data diperoleh dari dokumentasi yang tersedia dan hasil wawancara dengan pejabat/petugas /individu yang relevan dengan tujuan penelitian ini. Analisis penelitian dilakukan dengan memanfaatkan data sekunder yang tersedia di instansi serta observasi pada lembaga-lembaga teknis terkait, pengumpulan data, kompilasi dan analisis data.

\section{Lokasi dan Waktu Penelitian}

Penelitian ini dilaksanakan di kawasan andalan Kabupaten Bone Provinsi Sulawesi Selatan. Pemilihan lokasi didasarkan pada pertimbangan bahwa kawasan andalan Kabupaten Bone Provinsi Sulawesi Selatan sebagai kawasan yang mempunyai potensi sumberdaya alam pertanian tanaman pangan dan perkebunan yang mampu mendukung pembangunan pertanian
Provinsi Sulawesi Selatan. Penelitian ini berlangsung pada bulan Mei hingga Juni 2021.

\section{Jenis dan Sumber Data}

Data yang digunakan adalah sekunder, yaitu berupa data dokumentasi kinerja bidang pertanian tanaman pangan dan perkebunan kawasan andalan Kabupaten Bone Provinsi Sulawesi Selatan. Data ini diperoleh dari instansi terkait yang relevan serta pustaka yang mendukung penelitian ini. Selain data sekunder akan diambil pula data primer dari hasil wawancara dengan pejabatpejabat lingkup Dinas Pertanian Tanaman Pangan dan Hortikultura Kabupaten Bone serta pejabat yang berwenang. Data ini berupa informasi kebijakan-kebijakan yang mendasari munculnya kinerja pada data sekunder periode yang lalu dan informasi mengenai kebijakan lebih lanjut untuk mendukung pengembangan kawasan andalan Kabupaten Bone Provinsi Sulawesi Selatan.

\section{Teknik Analisis Data}

Analisis data yang digunakan adalah metode LQ. Analisis ini merupakan langkah awal untuk mengidentifikasi komoditi basis pada suatu daerah/wilayah. Teknik ini membandingkan antara kemampuan suatu daerah dalam menghasilkan suatu 
komoditi dengan daerah lain yang merupakan penghasil komoditi yang sama. Konsep tersebut dapat diformulasikan sebagai berikut (Warpani, 1984).

$$
\text { LQ } \frac{S i / S}{N i / N}
$$

Keterangan :

LQ = Besarnya koefisien lokasi komoditi pangan

$\mathrm{Si}=$ Jumlah (produksi) komoditi i pada tiap kecamatan

$\mathrm{S}=$ Jumlah (total produksi) pangan tingkat kecamatan

$\mathrm{Ni}=$ Jumlah produksi komoditi $\mathrm{i}$ pada tingkat kabupaten

$\mathrm{N}=$ Jumlah total produksi komoditi pangan tingkat kabupaten

Angka LQ memberikan indikasi sebagai berikut :

LQ > 1, menunjukkan komoditi tersebut adalah komoditi basis

LQ $<1$, menunjukkan komoditi tersebut adalah komoditi non basis

$\mathrm{LQ}=1$, menunjukkan komoditi tersebut hanya dapat mencukupi wilayah itu sendiri

\section{HASIL DAN PEMBAHASAN}

Metode Location Quotient (LQ), digunakan untuk menganalisis dan menentukan keragaman basis ekonomi. Teori basis ekonomi adalah salah satu pendekatan yang dapat digunakan di dalam identifikasi sektor potensial yang dapat menjadi motor penggerak pertumbuhan dan perkembangan wilayah. Berdasarkan analisis tersebut dapat diidentifikasi subsektor apa saja yang dapat dikembangkan untuk tujuan sektor dan tujuan memenuhi kebutuhan lokal, sehingga subsektor yang dikatakan potensial dapat dijadikan subsektor prioritas utama dalam perencanaan pembangunan perekonomian.

Komoditi yang mempunyai nilai LQ lebih besar dari 1 merupakan standar normatif untuk ditetapkan sebagai komoditi unggulan. Namun demikian, ketika banyak komoditi di suatu wilayah yang menghasilkan LQ lebih besar dari 1, sementara yang dicari adalah komoditi yang paling unggul, maka yang harus dipilih adalah komoditi yang memiliki nilai LQ tertinggi karena nilai LQ paling tinggi menunjukkan semakin tinggi pula potensi keunggulan komoditi tersebut. Komoditi yang menjadi unggulan di kawasan andalan Kabupaten Bone adalah komoditi padi yang merupakan komoditi basis di 20 kecamatan.

\section{Produksi Pertanian Tanaman Pangan}

Produksi pertanian tanaman pangan komoditi padi sektor basis di Kawasan Andalan Kabupaten Bone tersebar di 20 wilayah kecamatan yang memiliki nilai LQ > 1. Produksi komoditi jagung sektor basis di Kawasan Andalan Kabupaten Bone tersebar di 6 wilayah kecamatan dan produksi komoditi kacang kedelai sektor basis di Kawasan Andalan Kabupaten Bone tersebar di 9 wilayah kecamatan, dapat dilihat dalam penjelasan Tabel 1. 


\section{Produksi Tanaman Perkebunan}

Produksi komoditi tanaman kelapa sektor basis di Kawasan Andalan Kabupaten Bone tersebar di 23 wilayah kecamatan yang memiliki nilai LQ > 1 . Produksi komoditi kopi sektor basis di Kawasan Andalan Kabupaten Bone tersebar di 8 wilayah kecamatan. Produksi komoditi kakao sektor basis di Kawasan Andalan Kabupaten Bone tersebar di 23 wilayah kecamatan. Produksi komoditi tebu sektor basis di Kawasan Andalan Kabupaten Bone tersebar di 3 wilayah kecamatan dan produksi komoditi tembakau sektor basis di Kawasan Andalan Kabupaten Bone tersebar di 3 wilayah kecamatan. Lebih jelasnya dapat dilihat pada penjelasan Tabel 2 .

\section{KESIMPULAN DAN SARAN}

Hasil penelitian dan pembahasan dapat ditarik kesimpulan bahwa wilayah kecamatan yang memiliki komoditi padi sebagai komoditi sektor unggulan basis produksi LQ > 1, antara lain; Kecamatan Bontocani, Kahu, Salomekko, Tonra, Patimpeng, Libureng, Mare, Sibulue, Cina, Barebbo, Lappariaja, Lamuru, Tellu Limpoe, Bengo, Awangpone, Dua Boccoe, Cenrana, Tanete Riattang Barat, Tanete Riattang dan Tanete Riattang Timur. Wilayah kecamatan yang memiliki komoditi Jagung sebagai komoditi sektor unggulan basis produksi LQ > 1 , antara lain; Kecamatan Kajuara, Ponre, Ulaweng, Palakka, Tellu Siattinge, Amali dan Ajangale serta wilayah kecamatan yang memiliki komoditi kacang kedelai sebagai komoditi sektor unggulan basis produksi LQ > 1, antara lain; Kecamatan Kahu, Libureng, Cina, Ponre, Lappariaja, Palakka, Tanete Riattang Barat, Tanete Riattang dan Tanete Riattang Timur.

Hasil analisis menunjukkan bahwa wilayah kecamatan yang memiliki komoditi kelapa sebagai komoditi sektor unggulan basis produksi LQ > 1 , antara lain; Kecamatan Bontocani, Kajuara, Salomekko, Tonra, Sibulue, Cina, Barebbo, Ponre, Lappariaja, Lamuru, Tellu Limpoe, Bengo, Ulaweng, Palakka, Awangpone, Tellu Siatinge, Amali, Dua Boccoe, Ajangngale, Cenrana, Tanete Riattang Barat, Tanete Riattang dan Tanete Riattang Timur. Wilayah kecamatan yang memiliki komoditi kopi sebagai komoditi sektor unggulan basis produksi LQ > 1, antara lain; Kecamatan Bontocani, Salomekko, Tonra, Mare, Cina, Ponre, Tellu Limpoe dan Bengo. Wilayah kecamatan yang memiliki komoditi kakao sebagai komoditi sektor unggulan basis produksi LQ > 1 , antara lain; Kecamatan Bontocani, Kajuara, Salomekko, Tonra, Mare, Sibulue, Cina, 
Barebbo, Ponre, Lappariaja, Lamuru,

Tellu Limpoe, Bengo, Ulaweng, Palakka, Awangpone, Tellu Siatinge, Amali, Ajaengale, Dua Boccoe, Cenrana, Tanete

Riattang Barat dan Tanete Riattang. Wilayah kecamatan yang memiliki komoditi tebu sebagai komoditi sektor unggulan basis produksi LQ > 1 , antara lain; Kecamatan Kahu, Patimpeng dan Libureng serta Wilayah kecamatan yang memiliki komoditi tembakau sebagai komoditi sektor unggulan basis produksi LQ > 1, antara lain; Kecamatan Tellu Siatinge, Amali dan Dua Boccoe

\section{DAFTAR PUSTAKA}

Apriyantono, A., 2006. Sambutan Menteri Pertanian pada terbitnya buku Revitalisasi Pertanian, Dialog dan Peradaban, Penerbit Buku Kompas,Jakarta Maret 2006.

Arikunto, Suharsimi, 1997. Prosedur Penelitian Suatu Pendekatan Praktek. Rineka Cipta, Jakarta.

Badan Pusat Statistik Kabupaten Bone, 2019. Kabupaten Bone Dalam Angka, BPS Kabupaten Bone, Sulawesi Selatan.

Endro Pranoto, Potensi Wilayah Komoditas Pertanian Dalam Mendukung Ketahanan Pangan Berbasis Agribisnis Kabupaten Banyumas, Tesis Program Studi Agribisnis Universitas Diponegoro, Semarang, 2008.
Firdaus, Muhammad. (2007). Manajemen Agrbisnis. Jakarta: Penerbit Bumi Aksara

Jhingan M.L. 2012. Ekonomi Pembangunan dan Perencanaan. PT. Raja Grafindo Persada. Jakarta

Kuncoro, 2002, Evaluasi Penetapan Kawasan Andalan: Studi empiris di Kalimantan Selatan 1993-1999, Jurnal Ekonomi dan Bisnis Indonesia, Vol. 17, No.1, 2002

Syarief, Hidayat, Hardinsyah dan Sumali, 1999.Membenahi

Konsep Ketahanan Pangan Indonesia.Thaha, Hardinsyah dan Ala (Editor).Pembangunan Gizi dan Pangan Dari Perpektif Kemandirian Lokal, Perhimpunan Peminat Gizi dan Pangan. (PERGIZI PANGAN) Indonesia dan Center For Regional Resource Development \& Community Empowenment. Bogor.

Syarifudin L. 2003. Studi Pemilihan Subsektor Jasa Unggulan Dalam Rangka Mendukung Kota Bandung Sebagai Kota Jasa, Infomatek volume 5 Nomor 3 September 2003, Bandung

Warpani S. 1984. Analisis Kota dan Daerah. Institut Teknologi Bandung, Bandung. 
Tabel 1. Hasil Analisis LQ Untuk Komoditi Pertanian Tanaman Pangan

\begin{tabular}{|c|c|c|c|c|}
\hline No & Jenis Komoditi & $\begin{array}{c}\text { Produksi Kecamatan } \\
\text { (Ton) }\end{array}$ & $\begin{array}{c}\text { Produksi } \\
\text { Kabupaten (Ton) }\end{array}$ & Nilai LQ \\
\hline A & Kecamatan Bontocani & & & \\
\hline 1 & Padi & 34.506 & 1.393 .147 & 1,26 \\
\hline 2 & Jagung & 824 & 402.396 & 0,09 \\
\hline \multirow[t]{2}{*}{3} & Kacang Kedelai & 124 & 13.044 & 0,43 \\
\hline & Jumlah & 35.454 & 1.808 .587 & \\
\hline $\mathrm{B}$ & Kecamatan Kahu & & & \\
\hline 1 & Padi & 120.622 & 1.393 .147 & 1,22 \\
\hline 2 & Jagung & 6.592 & 402.396 & 0,23 \\
\hline \multirow[t]{2}{*}{3} & Kacang Kedelai & 1.056 & 13.044 & 1,14 \\
\hline & Jumlah & 128.270 & 1.808 .587 & \\
\hline $\mathrm{C}$ & Kecamatan Kajuara & & & \\
\hline 1 & Padi & 37.508 & 1.393 .147 & 0,88 \\
\hline 2 & Jagung & 17.152 & 402.396 & 1,41 \\
\hline \multirow[t]{2}{*}{3} & Kacang Kedelai & 339 & 13.044 & 0,86 \\
\hline & Jumlah & 54.999 & 1.808 .587 & \\
\hline $\mathrm{D}$ & Kecamatan Salomekko & & & \\
\hline 1 & Padi & 40.164 & 1.393 .147 & 1,14 \\
\hline 2 & Jagung & 5.561 & 402.396 & 0,55 \\
\hline \multirow[t]{2}{*}{3} & Kacang Kedelai & - & 13.044 & 0,00 \\
\hline & Jumlah & 45.725 & 1.808 .587 & \\
\hline $\mathrm{E}$ & Kecamatan Tonra & & & \\
\hline 1 & Padi & 26.072 & 1.393 .147 & 1,16 \\
\hline 2 & Jagung & 3.346 & 402.396 & 0,50 \\
\hline \multirow[t]{2}{*}{3} & Kacang Kedelai & - & 13.044 & 0,00 \\
\hline & Jumlah & 29.418 & 1.808 .587 & \\
\hline $\mathrm{F}$ & Kecamatan Patimpeng & & & \\
\hline 1 & Padi & 44.026 & 1.393 .147 & 1,12 \\
\hline 2 & Jagung & 6.833 & 402.396 & 0,59 \\
\hline \multirow[t]{2}{*}{3} & Kacang Kedelai & 229 & 13.044 & 0,71 \\
\hline & Jumlah & 51.088 & 1.808 .587 & \\
\hline $\mathrm{G}$ & Kecamatan Libureng & & & \\
\hline 1 & Padi & 117.400 & 1.393 .147 & 1,18 \\
\hline 2 & Jagung & 11.023 & 402.396 & 0,41 \\
\hline \multirow{2}{*}{3} & Kacang Kedelai & 1.138 & 13.044 & 1,29 \\
\hline & Jumlah & 129.561 & 1.808 .587 & \\
\hline $\mathrm{H}$ & Kecamatan Mare & & & \\
\hline 1 & Padi & 47.479 & 1.393 .147 & 1,14 \\
\hline 2 & Jagung & 6.268 & 402.396 & 0,55 \\
\hline \multirow[t]{2}{*}{3} & Kacang Kedelai & 109 & 13.044 & 0,29 \\
\hline & Jumlah & 53.856 & 1.808 .587 & \\
\hline I & Kecamatan Sibulue & & & \\
\hline 1 & Padi & 59.454 & 1.393 .147 & 1,21 \\
\hline 2 & Jagung & 4.512 & 402.396 & 0,32 \\
\hline \multirow[t]{2}{*}{3} & Kacang Kedelai & 128 & 13.044 & 0,29 \\
\hline & Jumlah & 64.094 & 1.808 .587 & \\
\hline $\mathrm{J}$ & Kecamatan Cina & & & \\
\hline 1 & Padi & 47.250 & 1.393 .147 & 1,19 \\
\hline 2 & Jagung & 3.052 & 402.396 & 0,27 \\
\hline \multirow[t]{2}{*}{3} & Kacang Kedelai & 893 & 13.044 & 2,86 \\
\hline & Jumlah & 51.195 & 1.808 .587 & \\
\hline K & Kecamatan Barebbo & & & \\
\hline 1 & Padi & 73.183 & 1.393 .147 & 1,21 \\
\hline
\end{tabular}




\begin{tabular}{|c|c|c|c|c|}
\hline 2 & Jagung & 4.162 & 402.396 & 0,23 \\
\hline 3 & Kacang Kedelai & 1.627 & 13.044 & 0,09 \\
\hline & Jumlah & 78.972 & 1.808 .587 & \\
\hline $\mathrm{L}$ & Kecamatan Ponre & & & \\
\hline 1 & Padi & 29.564 & 1.393 .147 & 0,92 \\
\hline 2 & Jagung & 10.744 & 402.396 & 1,18 \\
\hline \multirow[t]{2}{*}{3} & Kacang Kedelai & 986 & 13.044 & 2,86 \\
\hline & Jumlah & 41.294 & 1.808 .587 & \\
\hline $\mathrm{M}$ & Kecamatan Lappariaja & & & \\
\hline 1 & Padi & 61.658 & 1.393 .147 & 1,18 \\
\hline 2 & Jagung & 4.968 & 402.396 & 0,32 \\
\hline \multirow[t]{2}{*}{3} & Kacang Kedelai & 1.451 & 13.044 & 2,86 \\
\hline & Jumlah & 68.077 & 1.808 .587 & \\
\hline $\mathrm{N}$ & Kecamatan Lamuru & & & \\
\hline 1 & Padi & 33.206 & 1.393 .147 & 1,06 \\
\hline 2 & Jagung & 7.093 & 402.396 & 0,77 \\
\hline \multirow[t]{2}{*}{3} & Kacang Kedelai & 288 & 13.044 & 1,00 \\
\hline & Jumlah & 40.587 & 1.808 .587 & \\
\hline $\mathrm{O}$ & Kecamatan Tellu Limpoe & & & \\
\hline 1 & Padi & 18.495 & 1.393 .147 & 1,13 \\
\hline 2 & Jagung & 2.811 & 402.396 & 0,59 \\
\hline \multirow[t]{2}{*}{3} & Kacang Kedelai & 66 & 13.044 & 0,43 \\
\hline & Jumlah & 21.372 & 1.808 .587 & \\
\hline $\mathrm{P}$ & Kecamatan Bengo & & & \\
\hline 1 & Padi & 83.282 & 1.393 .147 & 1,19 \\
\hline 2 & Jagung & 6.528 & 402.396 & 0,32 \\
\hline \multirow[t]{2}{*}{3} & Kacang Kedelai & 411 & 13.044 & 0,71 \\
\hline & Jumlah & 90.221 & 1.808 .587 & \\
\hline $\mathrm{Q}$ & Kecamatan Ulaweng & & & \\
\hline 1 & Padi & 9.628 & 1.393 .147 & 0,22 \\
\hline 2 & Jagung & 48.690 & 402.396 & 3,77 \\
\hline \multirow[t]{2}{*}{3} & Kacang Kedelai & 32 & 13.044 & 0,14 \\
\hline & Jumlah & 58.350 & 1.808 .587 & \\
\hline $\mathrm{R}$ & Kecamatan Palakka & & & \\
\hline 1 & Padi & 37.991 & 1.393 .147 & 0,87 \\
\hline 2 & Jagung & 17.487 & 402.396 & 1,41 \\
\hline \multirow[t]{2}{*}{3} & Kacang Kedelai & 1.405 & 13.044 & 2,86 \\
\hline & Jumlah & 56.883 & 1.808 .587 & \\
\hline $\mathrm{S}$ & Kecamatan Awangpone & & & \\
\hline 1 & Padi & 62.883 & 1.393 .147 & 1,06 \\
\hline 2 & Jagung & 13.024 & 402.396 & 0,77 \\
\hline \multirow[t]{2}{*}{3} & Kacang Kedelai & 525 & 13.044 & 1,00 \\
\hline & Jumlah & 76.432 & 1.808 .587 & \\
\hline $\mathrm{T}$ & Kecamatan Tellu Siattinge & & & \\
\hline 1 & Padi & 65.810 & 1.393 .147 & 0,66 \\
\hline 2 & Jagung & 62.138 & 402.396 & 2,18 \\
\hline \multirow[t]{2}{*}{3} & Kacang Kedelai & 929 & 13.044 & 1,00 \\
\hline & Jumlah & 128.877 & 1.808 .587 & \\
\hline $\bar{U}$ & Kecamatan Amali & & & \\
\hline 1 & Padi & 8.596 & 1.393 .147 & 0,12 \\
\hline 2 & Jagung & 90.762 & 402.396 & 4,14 \\
\hline \multirow[t]{2}{*}{3} & Kacang Kedelai & - & 13.044 & 0,00 \\
\hline & Jumlah & 99.358 & 1.808 .587 & \\
\hline $\mathrm{V}$ & Kecamatan Ajangale & & & \\
\hline 1 & Padi & 82.251 & 1.393 .147 & 0,99 \\
\hline 2 & Jagung & 25.383 & 402.396 & 1,09 \\
\hline 3 & Kacang Kedelai & 91 & 13.044 & 0,11 \\
\hline
\end{tabular}




\begin{tabular}{|c|c|c|c|c|}
\hline & Jumlah & 107.725 & 1.808 .587 & \\
\hline $\mathrm{W}$ & Kecamatan Dua Boccoe & & & \\
\hline 1 & Padi & 142.177 & 1.393 .147 & 1,04 \\
\hline 2 & Jagung & 34.661 & 402.396 & 0,89 \\
\hline \multirow[t]{2}{*}{3} & Kacang Kedelai & - & 13.044 & 0,00 \\
\hline & Jumlah & 176.838 & 1.808 .587 & \\
\hline $\mathrm{X}$ & Kecamatan Cenrana & & & \\
\hline 1 & Padi & 49.492 & 1.393 .147 & 1,19 \\
\hline 2 & Jagung & 3.984 & 402.396 & 0,32 \\
\hline \multirow[t]{2}{*}{3} & Kacang Kedelai & 198 & 13.044 & 0,57 \\
\hline & $\begin{array}{ll}\text { Jumlah } \\
\end{array}$ & 53.674 & 1.808 .587 & \\
\hline $\mathrm{Y}$ & Kecamatan Tanete Riattang Barat & & & \\
\hline 1 & Padi & 17.415 & 1.393 .147 & 1,09 \\
\hline 2 & Jagung & 2.984 & 402.396 & 0,64 \\
\hline \multirow[t]{2}{*}{3} & Kacang Kedelai & 273 & 13.044 & $\mathbf{1 , 8 6}$ \\
\hline & $\begin{array}{ll}\text { Jumlah } \\
\end{array}$ & 20.672 & 1.808 .587 & \\
\hline $\mathrm{Z}$ & Kecamatan Tanete Riattang & & & \\
\hline 1 & Padi & 16.531 & 1.393 .147 & 1,22 \\
\hline 2 & Jagung & 808 & 402.396 & 0,23 \\
\hline \multirow[t]{2}{*}{3} & Kacang Kedelai & 294 & 13.044 & 2,86 \\
\hline & Jumlah & 17.633 & 1.808 .587 & \\
\hline \multicolumn{5}{|c|}{ Kecamatan Tanete Riattang Timur } \\
\hline 1 & Padi & 26.504 & 1.393 .147 & 1,23 \\
\hline 2 & Jagung & 1.006 & 402.396 & 0,18 \\
\hline \multirow[t]{2}{*}{3} & Kacang Kedelai & 452 & 13.044 & 2,86 \\
\hline & Jumlah & 27.962 & 1.808 .587 & \\
\hline
\end{tabular}

Sumber : Hasil Olahan Data, 2021

Tabel 2. Hasil Analisis LQ Untuk Komoditi Tanaman Perkebunan

\begin{tabular}{|c|c|c|c|c|}
\hline No & Jenis Komoditi & $\begin{array}{l}\text { Produksi } \\
\text { Kecamatan } \\
\text { (Ton) }\end{array}$ & $\begin{array}{l}\text { Produksi } \\
\text { Kabupaten } \\
\text { (Ton) }\end{array}$ & Nilai LQ \\
\hline $\mathbf{A}$ & Kecamatan Bontocani & & & \\
\hline 1 & Kelapa & 81 & 12.346 & 1,62 \\
\hline 2 & Kopi & 173 & 319 & 1,47 \\
\hline 3 & Kakao & 138 & 10.700 & 3,18 \\
\hline 4 & Tebu & - & 69.634 & 0,00 \\
\hline \multirow[t]{2}{*}{5} & Tembakau & - & 765 & 0,00 \\
\hline & Jumlah & 392 & 93.764 & \\
\hline B & Kecamatan Kahu & & & \\
\hline 1 & Kelapa & 498 & 12.346 & 0,15 \\
\hline 2 & Kopi & 9 & 319 & 0,14 \\
\hline 3 & Kakao & 914 & 10.700 & 0,38 \\
\hline 4 & Tebu & 20.235 & 69.634 & 1,26 \\
\hline \multirow[t]{2}{*}{5} & Tembakau & - & 765 & 0,00 \\
\hline & Jumlah & 21.656 & 93.764 & \\
\hline $\mathbf{C}$ & Kecamatan Kajuara & & & \\
\hline 1 & Kelapa & 180 & 12.346 & 6,05 \\
\hline 2 & Kopi & - & 319 & 0,00 \\
\hline 3 & Kakao & 49 & 10.700 & 1,95 \\
\hline 4 & Tebu & - & 69.634 & 0,00 \\
\hline \multirow[t]{2}{*}{5} & Tembakau & - & 765 & 0,00 \\
\hline & Jumlah & 229 & 93.764 & \\
\hline D & Kecamatan Salomekko & & & \\
\hline 1 & Kelapa & 139 & 12.346 & 6,01 \\
\hline 2 & Kopi & 1 & 319 & 1,87 \\
\hline 3 & Kakao & 38 & 10.700 & 1,94 \\
\hline
\end{tabular}




\begin{tabular}{|c|c|c|c|c|}
\hline 4 & Tebu & - & 69.634 & 0,00 \\
\hline \multirow[t]{2}{*}{5} & Tembakau & - & 765 & 0,00 \\
\hline & Jumlah & 178 & 93.764 & \\
\hline $\mathbf{E}$ & Kecamatan Tonra & & & \\
\hline 1 & Kelapa & 164 & 12.346 & 2,63 \\
\hline 2 & Kopi & 4 & 319 & 2,78 \\
\hline 3 & Kakao & 311 & 10.700 & 5,90 \\
\hline 4 & Tebu & - & 69.634 & 0,00 \\
\hline \multirow{2}{*}{5} & Tembakau & - & 765 & 0,00 \\
\hline & Jumlah & 479 & 93.764 & \\
\hline $\mathbf{F}$ & Kecamatan Patimpeng & & & \\
\hline 1 & Kelapa & 256 & 12.346 & 0,40 \\
\hline 2 & Kopi & - & 319 & 0,00 \\
\hline 3 & Kakao & 421 & 10.700 & 0,77 \\
\hline 4 & Tebu & 4.274 & 69.634 & 1,17 \\
\hline \multirow[t]{2}{*}{5} & Tembakau & - & 765 & 0,00 \\
\hline & Jumlah & 4.951 & 93.764 & \\
\hline $\mathbf{G}$ & Kecamatan Libureng & & & \\
\hline 1 & Kelapa & 69 & 12.346 & 0,01 \\
\hline 2 & Kopi & 1 & 319 & 0,01 \\
\hline 3 & Kakao & 1.416 & 10.700 & 0,28 \\
\hline 4 & Tebu & 45.124 & 69.634 & 1,31 \\
\hline \multirow[t]{2}{*}{5} & Tembakau & - & 765 & 0,00 \\
\hline & Jumlah & 46.610 & 93.764 & \\
\hline $\mathbf{H}$ & Kecamatan Mare & & & \\
\hline 1 & Kelapa & 50 & 12.346 & 0,75 \\
\hline 2 & Kopi & 2 & 319 & 1,30 \\
\hline 3 & Kakao & 461 & 10.700 & 8,17 \\
\hline 4 & Tebu & - & 69.634 & 0,00 \\
\hline \multirow[t]{2}{*}{5} & Tembakau & - & 765 & 0,00 \\
\hline & Jumlah & 513 & 93.764 & \\
\hline $\mathbf{I}$ & Kecamatan Sibulue & & & \\
\hline 1 & Kelapa & 734 & 12.346 & 6,40 \\
\hline 2 & Kopi & - & 319 & 0,00 \\
\hline 3 & Kakao & 148 & 10.700 & 1,53 \\
\hline 4 & Tebu & - & 69.634 & 0,00 \\
\hline \multirow[t]{2}{*}{5} & Tembakau & - & 765 & 0,00 \\
\hline & Jumlah & 882 & 93.764 & \\
\hline $\mathbf{J}$ & Kecamatan Cina & & & \\
\hline 1 & Kelapa & 87 & 12.346 & 1,87 \\
\hline 2 & Kopi & 3 & 319 & 2,79 \\
\hline 3 & Kakao & 268 & 10.700 & 6,81 \\
\hline 4 & Tebu & - & 69.634 & 0,00 \\
\hline \multirow[t]{2}{*}{5} & Tembakau & - & 765 & 0,00 \\
\hline & Jumlah & 358 & 93.764 & \\
\hline $\mathbf{K}$ & Kecamatan Barebbo & & & \\
\hline 1 & Kelapa & 77 & 12.346 & 2,69 \\
\hline 2 & Kopi & - & 319 & 0,00 \\
\hline 3 & Kakao & 143 & 10.700 & 5,91 \\
\hline 4 & Tebu & - & 69.634 & 0,00 \\
\hline \multirow[t]{2}{*}{5} & Tembakau & - & 765 & 0,00 \\
\hline & Jumlah & 220 & 93.764 & \\
\hline $\mathbf{L}$ & Kecamatan Ponre & & & \\
\hline 1 & Kelapa & 179 & 12.346 & 1,84 \\
\hline 2 & Kopi & 6 & 319 & 2,67 \\
\hline 3 & Kakao & 564 & 10.700 & 6,85 \\
\hline 4 & Tebu & - & 69.634 & 0,00 \\
\hline
\end{tabular}




\begin{tabular}{|c|c|c|c|c|}
\hline 5 & Tembakau & - & 765 & 0,00 \\
\hline & Jumlah & 749 & 93.764 & \\
\hline $\mathbf{M}$ & Kecamatan Lappariaja & & & \\
\hline 1 & Kelapa & 938 & 12.346 & 4,46 \\
\hline 2 & Kopi & 1 & 319 & 0,21 \\
\hline 3 & Kakao & 679 & 10.700 & 3,82 \\
\hline 4 & Tebu & - & 69.634 & 0,00 \\
\hline \multirow[t]{2}{*}{5} & Tembakau & - & 765 & 0,00 \\
\hline & Jumlah & 1.618 & 93.764 & \\
\hline $\mathbf{N}$ & Kecamatan Lamuru & & & \\
\hline 1 & Kelapa & 810 & 12.346 & 2,64 \\
\hline 2 & Kopi & 5 & 319 & 0,71 \\
\hline 3 & Kakao & 1.542 & 10.700 & 5,95 \\
\hline 4 & Tebu & - & 69.634 & 0,00 \\
\hline \multirow[t]{2}{*}{5} & Tembakau & - & 765 & 0,00 \\
\hline & Jumlah & 2.357 & 93.764 & \\
\hline $\mathbf{O}$ & Kecamatan Tellu Limpoe & & & \\
\hline 1 & Kelapa & 153 & 12.346 & 2,50 \\
\hline 2 & Kopi & 106 & 319 & 7,52 \\
\hline 3 & Kakao & 211 & 10.700 & 4,08 \\
\hline 4 & Tebu & - & 69.634 & 0,00 \\
\hline \multirow[t]{2}{*}{5} & Tembakau & - & 765 & 0,00 \\
\hline & Jumlah & 470 & 93.764 & \\
\hline $\mathbf{P}$ & Kecamatan Bengo & & & \\
\hline 1 & Kelapa & 656 & 12.346 & 4,11 \\
\hline 2 & Kopi & 9 & 319 & 2,44 \\
\hline 3 & Kakao & 559 & 10.700 & 4,13 \\
\hline 4 & Tebu & - & 69.634 & 0,00 \\
\hline \multirow[t]{2}{*}{5} & Tembakau & 5 & 765 & 0,51 \\
\hline & Jumlah & 1.229 & 93.764 & \\
\hline $\mathbf{Q}$ & Kecamatan Ulaweng & & & \\
\hline 1 & Kelapa & 92 & 12.346 & 1,37 \\
\hline 2 & Kopi & - & 319 & 0,00 \\
\hline 3 & Kakao & 423 & 10.700 & 7,45 \\
\hline 4 & Tebu & - & 69.634 & 0,00 \\
\hline \multirow[t]{2}{*}{5} & Tembakau & - & 765 & 0,00 \\
\hline & Jumlah & 515 & 93.764 & \\
\hline $\mathbf{R}$ & Kecamatan Palakka & & & \\
\hline 1 & Kelapa & 656 & 12.346 & 4,80 \\
\hline 2 & Kopi & - & 319 & 0,00 \\
\hline 3 & Kakao & 396 & 10.700 & 3,42 \\
\hline 4 & Tebu & - & 69.634 & 0,00 \\
\hline \multirow[t]{2}{*}{5} & Tembakau & - & 765 & 0,00 \\
\hline & Jumlah & 1.052 & 93.764 & \\
\hline $\mathbf{S}$ & Kecamatan Awangpone & & & \\
\hline 1 & Kelapa & 351 & 12.346 & 4,28 \\
\hline 2 & Kopi & - & 319 & 0,00 \\
\hline 3 & Kakao & 278 & 10.700 & 4,01 \\
\hline 4 & Tebu & - & 69.634 & 0,00 \\
\hline \multirow[t]{2}{*}{5} & Tembakau & 2 & 765 & 0,40 \\
\hline & Jumlah & 631 & 93.764 & \\
\hline $\mathbf{T}$ & Kecamatan Tellu Siattinge & & & \\
\hline 1 & Kelapa & 2.467 & 12.346 & 5,46 \\
\hline 2 & Kopi & - & 319 & 0,00 \\
\hline 3 & Kakao & 560 & 10.700 & 1,46 \\
\hline 4 & Tebu & - & 69.634 & 0,00 \\
\hline 5 & Tembakau & 451 & 765 & 1,62 \\
\hline
\end{tabular}




\begin{tabular}{|c|c|c|c|c|}
\hline & Jumlah & 3.478 & 93.764 & \\
\hline $\mathbf{U}$ & Kecamatan Amali & & & \\
\hline 1 & Kelapa & 1.066 & 12.346 & 4,37 \\
\hline 2 & Kopi & - & 319 & 0,00 \\
\hline 3 & Kakao & 604 & 10.700 & 2,93 \\
\hline 4 & Tebu & - & 69.634 & 0,00 \\
\hline \multirow[t]{2}{*}{5} & Tembakau & 207 & 765 & 1,38 \\
\hline & Jumlah & 1.877 & 93.764 & \\
\hline $\mathbf{V}$ & Kecamatan Ajangale & & & \\
\hline 1 & Kelapa & 765 & 12.346 & 6,49 \\
\hline 2 & Kopi & - & 319 & 0,00 \\
\hline 3 & Kakao & 143 & 10.700 & 1,43 \\
\hline 4 & Tebu & - & 69.634 & 0,00 \\
\hline \multirow[t]{2}{*}{5} & Tembakau & - & 765 & 0,00 \\
\hline & Jumlah & 908 & 93.764 & \\
\hline W & Kecamatan Dua Boccoe & & & \\
\hline 1 & Kelapa & 1.319 & 12.346 & 6,09 \\
\hline 2 & Kopi & - & 319 & 0,00 \\
\hline 3 & Kakao & 246 & 10.700 & 1,14 \\
\hline 4 & Tebu & - & 69.634 & 0,00 \\
\hline \multirow[t]{2}{*}{5} & Tembakau & 101 & 765 & 7,57 \\
\hline & Jumlah & 1.666 & 93.764 & \\
\hline $\mathbf{X}$ & Kecamatan Cenrana & & & \\
\hline 1 & Kelapa & 450 & 12.346 & 5,82 \\
\hline 2 & Kopi & - & 319 & 0,00 \\
\hline 3 & Kakao & 145 & 10.700 & 2,22 \\
\hline 4 & Tebu & - & 69.634 & 0,00 \\
\hline \multirow[t]{2}{*}{5} & Tembakau & - & 765 & 0,00 \\
\hline & Jumlah & 595 & 93.764 & \\
\hline $\mathbf{Y}$ & Kecamatan Tanete Riattang Barat & & & \\
\hline 1 & Kelapa & 67 & 12.346 & 5,05 \\
\hline 2 & Kopi & - & 319 & 0,00 \\
\hline 3 & Kakao & 35 & 10.700 & 3,12 \\
\hline 4 & Tebu & - & 69.634 & 0,00 \\
\hline \multirow[t]{2}{*}{5} & Tembakau & - & 765 & 0,00 \\
\hline & Jumlah & 102 & 93.764 & \\
\hline $\mathbf{Z}$ & Kecamatan Tanete Riattang & & & \\
\hline 1 & Kelapa & 20 & 12.346 & 6,15 \\
\hline 2 & Kopi & - & 319 & 0,00 \\
\hline 3 & Kakao & 5 & 10.700 & 1,82 \\
\hline 4 & Tebu & - & 69.634 & 0,00 \\
\hline \multirow[t]{2}{*}{5} & Tembakau & - & 765 & 0,00 \\
\hline & Jumlah & 25 & 93.764 & \\
\hline AA & Kecamatan Tanete Riattang Timur & & & \\
\hline 1 & Kelapa & 24 & 12.346 & 6,84 \\
\hline 2 & Kopi & - & 319 & 0,00 \\
\hline 3 & Kakao & 3 & 10.700 & 1,00 \\
\hline 4 & Tebu & - & 69.634 & 0,00 \\
\hline \multirow[t]{2}{*}{5} & Tembakau & - & 765 & 0,00 \\
\hline & Jumlah & 27 & 93.764 & \\
\hline
\end{tabular}

